\title{
Hot Water Treatment Enhances the Bioherbicidal Efficacy of a Fungus
}

\author{
C. Douglas Boyette ${ }^{1 *}$, Robert E. Hoagland ${ }^{2}$, Kenneth C. Stetina ${ }^{1}$ \\ ${ }^{1}$ USDA-ARS, Biological Control of Pests Research Unit, Stoneville, MS, USA \\ ${ }^{2}$ USDA-ARS, Crop Production and Systems Research Unit, Stoneville, MS, USA \\ Email: *doug.boyette@ars.usda.gov
}

How to cite this paper: Boyette, C.D., Hoagland, R.E. and Stetina, K.C. (2018) Hot Water Treatment Enhances the Bioherbicidal Efficacy of a Fungus. American Journal of Plant Sciences, 9, 2063-2072. https://doi.org/10.4236/ajps.2018.910150

\section{Received: July 30, 2018}

Accepted: September 25, 2018

Published: September 28, 2018

Copyright ( 92018 by authors and Scientific Research Publishing Inc. This work is licensed under the Creative Commons Attribution International License (CC BY 4.0).

http://creativecommons.org/licenses/by/4.0/

\section{cc) (i) Open Access}

\begin{abstract}
Hemp sesbania (Sesbania exaltata) plants $(>30 \mathrm{~cm}$ tall) sprayed with hot water $\left(45^{\circ} \mathrm{C}-95^{\circ} \mathrm{C}\right)$, followed by spray applications of fungal spores of Colletotrichum truncatum (CT) at $1.0 \times 10^{7}$ spores $/ \mathrm{ml}^{-1}$ and $22^{\circ} \mathrm{C}-25^{\circ} \mathrm{C}$, suspended either in: $0.2 \%$ Silwet L-77 surfactant (SW); unrefined corn oil (CO)/distilled water (1:1, v:v); or $0.2 \%$ SW in CO were controlled by $80 \%-95 \%, 12$ days after treatment (DAT) under greenhouse conditions. These treatments also reduced dry weight accumulation of this weed. Plants treated with hot water without CT were also injured at temperatures $\geq 35^{\circ} \mathrm{C}$ ( $5 \%$ mortality), and $60 \%$ mortality at $95^{\circ} \mathrm{C}$. Artificial dew treatments $\left(25^{\circ} \mathrm{C}, 12 \mathrm{~h}\right)$, imposed on plants after the treatment protocols above, had little or no effect on weed mortality or dry weight reduction compared to treated plants without dew. Under field conditions, $85 \%$ control of hemp sesbania was achieved $12-15$ DAT when a pre-treatment with hot water $\left(65^{\circ} \mathrm{C}\right)$ was followed immediately with a CT application at the spore concentration as described above. Plants in field tests treated with $\mathrm{CT}$ without a hot water treatment were visually unaffected, with no mortality or plant biomass reductions recorded 15 DAT. These results suggest that use of hot water may be an important tool for improving the infectivity and bioherbicidal potential of some plant pathogens.
\end{abstract}

\section{Keywords}

Bioherbicide, Mycoherbicide, Hemp Sesbania, Sesbania exaltata, Colletotrichum truncatum, Hot Water Pre-Treatment, Improved Bioherbicide Efficacy, Weed Control

\section{Introduction}

Heat is a valuable entity that has served a variety of needs throughout human history (e.g., warmth, warfare, cooking, food preservation, etc.), but only rela- 
tively recently has heat been used for weed control, where it may serve as an alternative to chemical herbicides. Much of the research involved with heat to control weeds has been via four general methods: controlled burning, flaming of weeds, hot water treatment and steam application. Heat injury can cause denaturation/aggregation of cellular proteins and protoplast expansion/rupture, resulting in plant tissue desiccation, potentially leading to death [1] [2]. Depending on the heat treatment exposure time, protein denaturation in plant tissues may be initiated at $45^{\circ} \mathrm{C}$ [3] [4]. Temperatures of $55^{\circ} \mathrm{C}-95^{\circ} \mathrm{C}$ can be lethal to plant leaf and stem tissues [5] [6] [7]. Exposure to a flame for only $0.065-0.130$ s was sufficient to kill leaf tissue [5] [8] and higher temperatures were more effective. For example, cellular structural changes were more pronounced when the cellular temperature changed more rapidly (e.g., flaming) compared to gradual and lower temperature changes (e.g., hot-water treatment) [5]. Since many of these treatments only kill plant shoots, the affected plants (especially perennial weeds) may regenerate, making repeated treatments necessary [1] [2].

Controlled burning can achieve several land management objectives, but has low value for weed control. In a survey of experimental burning to reduce invasive plants, only $25 \%$ of the test sites were unequivocally successful, but $75 \%$ failed because there was no effect, the target species increased, or other invasive species invaded [9]. Thus, controlled burning is used mainly for reasons other than weed control, and may even enhance weed problems.

Flame weeding is the most widely used thermal weed control method, wherein flaming heats plant tissues rapidly to rupture cells, without burning [10]. Large-scale agricultural application of flaming began in the early 1940s for selective weed control in cotton in the U.S. Flame weeding was widely used in the U.S. from the 1940s to the mid-1960s, in some agronomic crops (cotton, maize, soybeans), and vegetable and fruit crops [11] [12]. Usually, flaming is applied as a single application for non-selective weed control prior to crop emergence in carrots and other slow-emerging row crops [13] [14]. Flaming before crop emergence, followed by post-emergence mechanical inter- and intra-row weeding, has been useful [15]. Selective post-emergence flaming has also been used on heat-tolerant crops (e.g. maize and onions) when soil was too wet for mechanical cultivation [16], to control weeds on hard surfaces in urban areas and for desiccation of potato haulms to aid tuber harvest [12].

Technologies to control weeds by application of hot water or steam [17] [18] [19] [20] have also been developed. After treatment with steam or hot water, plant leaves change color rapidly (minutes), with desiccation occurring within days. Hot water has been useful for weed control in orchards and as a foliar spray, applied directly to the soil surface and/or by injection into the soil [21] [22]. Hot water treatment may provide a method of choice for small or environmentally sensitive areas, spot treatments, weed control around poles, near fences, cracks in concrete and asphalt, and gravel. The use of this method can be costly, requiring large amounts of water and energy [10], but compared with 
flaming, hot water application has better canopy penetration with no fire hazard [22].

Synthetic herbicides have been a tremendous asset to weed control in agriculture; however, weed control problems still exist, and many weeds have developed resistance to herbicides [23]. An alternative to synthetic herbicides for weed control is the concept of bioherbicides. Bioherbicides are microbes and/or microbial phytotoxins used to control weeds. This approach to weed control (largely developed during the 1970s), has continued, with world-wide efforts as evidenced in several books [24] [25] [26] and reviews [27]-[37] dedicated to bioherbicides. In order for bioherbicide usage to become more predictable, effective and acceptable, it is necessary to maximize the ability of a bioherbicide to infect, kill and/or reduce the competitiveness of weed hosts. Previous research in our laboratory and elsewhere has shown that certain formulations, such as invert (water-in-oil) emulsions and various vegetable oil-in-water emulsions can retard evaporation and trap water in bioherbicide spray mixtures, thereby decreasing the amount of additional free-moisture required to initiate spore germination and infection [38]-[44]. For example, greenhouse and field results indicated that $>95 \%$ control of sicklepod (Senna obtusifolia L.) could be achieved with little or no dew using an invert formulation of the fungus Alternaria cassiae Jurair \& Khan [39].

The fungus Colletotrichum truncatum (Schwein.) Andrus \& W.D. Moore (CT) has shown bioherbicidal potential to control hemp sesbania [41] [45]. As outlined above, spores (conidia) of this fungus require certain periods of sustained free-moisture (dew) in order to germinate, establish infection, and cause disease [41] [46] [47]. However, hemp sesbania was effectively controlled in soybean by CT spores formulated in a water-in-oil invert emulsion, applied using specialized spraying equipment [air-assist nozzles] [41]. Even though the invert formulation provided excellent hemp sesbania control ( $>90 \%)$, the difficulty in applying this viscous mixture precluded its practical usage. In other experiments, oil-in-water emulsions of unrefined corn oil and CT spore suspensions reduced the dew period requirements for maximum weed infection and mortality of hemp sesbania from $12 \mathrm{~h}$ to $2 \mathrm{~h}$, and delayed the need for free-moisture for greater than $72 \mathrm{~h}$ [42]. Unrefined corn oil (but not refined corn oil) also stimulated CT spore germination [43] [48]. A surfactant (Silwet L-77) (SW, OSi Specialties, Inc., Danbury, CT, USA) incorporated in an unrefined corn oil emulsion also promoted germination and infectivity of Alternaria helianthi (Hansf) Tubaki \& Nishihara spores on common cocklebur (Xanthium strumarium L.) [49].

Because hot water and steam can denature plant proteins [1] [2] (some of which may be related to plant defense against pathogens), and alter plant epicuticular waxes (barriers to pathogens), we hypothesized that hot water treatment, followed by a bioherbicide application might promote the efficacy a given pathogen for control of certain weeds. Therefore, we chose to examine the effects of hot water applications and CT (applied or formulated with corn oil emulsions 
and Silwet L-77) under greenhouse and field conditions for the control of hemp sesbania, an important weed in row crops in the southern U.S. [50] that has also been reported to have tolerance to glyphosate [51] [52].

\section{Materials and Methods}

\subsection{Laboratory and Greenhouse Experiments}

\subsubsection{Source and Maintenance of $C$. truncatum}

A single strain of C. truncatum (Agricultural Research Service Patent Culture Collection, NRRL 18434) was used in these studies. The fungus was preserved in screw-capped tubes containing sterilized soil [53]. Cultures were grown on potato dextrose agar (PDA; Difco Laboratories, Detroit, MI, USA) in plastic petri dishes (10 cm diameter) that were inverted on open-mesh wire shelves of a Percival I-35LLVL (Model I-36 DL; Percival Sci. Ind., Perry, IA, USA) incubator at $25^{\circ} \mathrm{C}$ under cool, white fluorescent lighting ( $12 \mathrm{~h}$ photoperiod). Cultures were aseptically transferred to PDA every $5-7$ days in a biological safety cabinet $(\mathrm{Nu}$ Aire, Model Nu-425-400, Nu Aire Laboratory Equipment, Plymouth, MN, USA). Spores were harvested by rinsing the cultures with deionized-distilled water and straining through double-layered cheesecloth. Spore densities were determined with hemocytometers and dilutions were made with deionized-distilled water to give the desired inoculum concentrations for testing. Unrefined corn oil (CO) (Spectrum's Natural, Petaluma, CA, USA) emulsion formulations were prepared by adding a 1:1 ratio of CO: to deionized-distilled water. The spores were mixed with the emulsion or Silwet L-77 surfactant (SW) (OSI Specialties, Inc., Danbury, CT, USA) using a vortex mixer.

Preliminary experiments to ensure pathogen virulence and efficacy were conducted by spraying hemp sesbania seedlings (cotyledonary stage) at a concentration of $1.0 \times 10^{7}$ conidia $\cdot \mathrm{ml}^{-1}$ (formulated in $0.20 \% \mathrm{SW}$ ) until runoff, then placing them in a dew chamber (Percival, Model DL, Boone, IA, USA), (100\% RH, $25^{\circ} \mathrm{C}$ ) for $12 \mathrm{~h}$, with subsequent transfer to greenhouse benches. These biological and physical conditions routinely resulted in $95 \%-100 \%$ control of these young plants at $24-48 \mathrm{~h}$ after treatment [46].

\subsubsection{Test Plant Propagation in Greenhouse}

Hemp sesbania plants were grown from mechanically-scarified seed in a commercial potting mix contained in peat strips (12 plants per strip). The potting mix was supplemented with a controlled-release (14:14:14, N:P:K) fertilizer. The plants were placed in sub-irrigated trays that were mounted on greenhouse benches. Greenhouse temperatures ranged from $25^{\circ} \mathrm{C}-30^{\circ} \mathrm{C}$ with $40 \%-90 \%$ relative humidity (RH). The photoperiod was $12 \mathrm{~h}$ with $1650 \mu \mathrm{mol} \cdot \mathrm{m}^{-2} \cdot \mathrm{s}^{-1}$ photosynthetic photon flux measured at midday.

\subsubsection{Plant Inoculations-Greenhouse Experiments}

Hemp sesbania was grown until the plants were in the $7-10$ leaf growth stage $(\geq$ $30 \mathrm{~cm}$ ). We chose to examine relatively large plants, because previous research 
showed that hemp sesbania plants of this size were minimally affected by this fungus [46].

A schematic outline summarizes the treatments in the greenhouse experiments (Figure 1). Plants were separated into two main groups: 1) plants receiving a dew treatment; 2) plants without a dew treatment. Formulations (SW) and corn oil (unrefined; CO), successfully used in previous research to control seedling (but not large) hemp sesbania plants [42] [47] [48] were utilized. For plants receiving a hot water pre-treatment, deionized-distilled water contained in 2-L flasks was heated via microwave until boiling (about $100^{\circ} \mathrm{C}$ ). As the temperature of the water cooled, $250 \mathrm{ml}$ aliquots were decanted into $500 \mathrm{ml}$ beakers and sprayed until runoff (about $200 \mathrm{~L} \cdot \mathrm{ha}^{-1}$ ) on hemp sesbania plants (ca $30 \mathrm{~cm}$ tall) using a hand-held compressed air sprayer (Spray-Tool, Aervoe Industries, Gardnerville, NV, USA) at temperatures from $95^{\circ} \mathrm{C}$ to $25^{\circ} \mathrm{C}$, at $5^{\circ} \mathrm{C}$ increments, as monitored with a digital thermometer. Following the hot water pre-treatment, seedlings were sprayed with CT spores $\left(1.0 \times 10^{7}\right.$ conidia $\cdot \mathrm{ml}^{-1}$ until runoff) prepared in the aqueous carriers [either $0.2 \%$ (v:v) SW, or $0.2 \% \mathrm{SW}+\mathrm{CO}(1: 1, \mathrm{v}: \mathrm{v})$ ] and placed in a dew chamber or directly on greenhouse benches as described above. Plant mortality and dry weight reduction data were recorded 15 DAT. The term mortality (plant death) was applied to plants that were devoid of chlorophyll, that exhibited collapsed stems and had a high degree of necrosis. Plants were deemed survivors if they retained some green tissue and turgor pressure.

\subsection{Plant Inoculations-Field Experiments}

Field experiments were conducted in the late spring (June) at the USDA-ARS Southern Weed Science Experimental Farm, Stoneville, MS, USA. The experiments

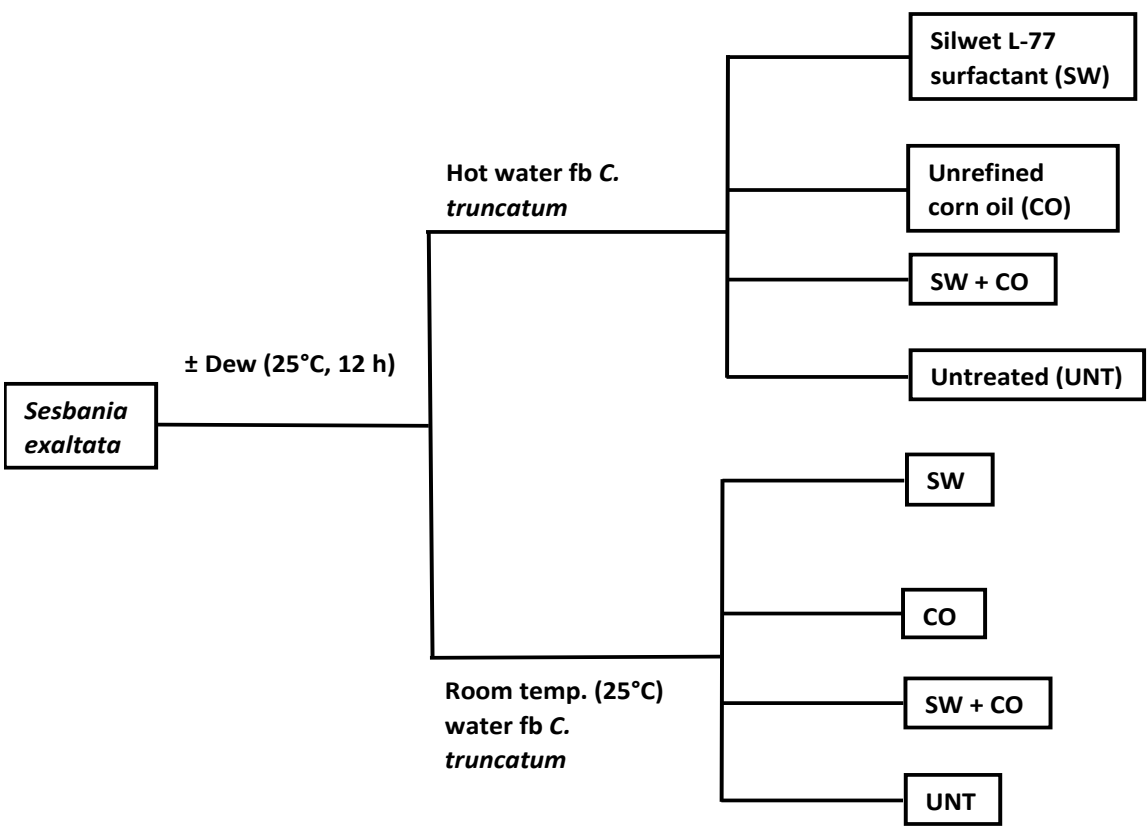

Figure 1. Schematic summarizing the treatments in the greenhouse experiments. 
were established in $0.50 \times 8.0 \mathrm{~m}$ plots, seeded with hemp sesbania (about 250 seeds.plot $\left.{ }^{-1}\right)$. The plots were irrigated regularly, and a vigorous emergence of hemp sesbania occurred after 10 days. Within each plot, 20 test plants were randomly selected and marked using wooden stakes $(7.6 \mathrm{~cm}$ long). Treatments were applied after the plants had reached an average height of about $30 \mathrm{~cm}$. Hot water was prepared by heating distilled water to the desired temperature $\left(65^{\circ} \mathrm{C}\right)$ on a hot plate in the laboratory and then decanting into a $12 \mathrm{~L}$ insulated water cooler prior to transport to the field. The experiment consisted of eight treatments: 1) $\mathrm{H}_{2} \mathrm{O}\left(25^{\circ} \mathrm{C}\right)$ followed by (fb) SW; 2) $\mathrm{H}_{2} \mathrm{O}\left(65^{\circ} \mathrm{C}\right) \mathrm{fb} \mathrm{SW}$; 3) $\mathrm{H}_{2} \mathrm{O}\left(25^{\circ} \mathrm{C}\right) \mathrm{fb}$ $\mathrm{SW}+\mathrm{CO}$; 4) $\left.\left.\mathrm{H}_{2} \mathrm{O}\left(65^{\circ} \mathrm{C}\right) \mathrm{fb} \mathrm{SW}+\mathrm{CO} ; 5\right) \mathrm{H}_{2} \mathrm{O}\left(2^{\circ} \mathrm{C}\right) \mathrm{fb} \mathrm{SW}+\mathrm{CT} ; 6\right) \mathrm{H}_{2} \mathrm{O}\left(65^{\circ} \mathrm{C}\right) \mathrm{fb}$ $\mathrm{SW}+\mathrm{CT}$; 7) $\mathrm{H}_{2} \mathrm{O}\left(25^{\circ} \mathrm{C}\right)$ fb SW+CO+CT; and 8$) \mathrm{H}_{2} \mathrm{O}\left(65^{\circ} \mathrm{C}\right) \mathrm{fb} \mathrm{SW}+\mathrm{CO}+\mathrm{CT}$. Inoculum and adjuvant concentrations were as described above in the laboratory experiments. All spray applications were made with back-pack sprayers (Gilmour, Somerset, PA, USA) at spray volumes of about $200 \mathrm{~L} \cdot \mathrm{ha}^{-1}$. The selected plants were monitored for injury at 3-day intervals for 15 days, at which time the selected plants were harvested, oven-dried $\left(80^{\circ} \mathrm{C}, 72 \mathrm{~h}\right)$, and biomass dry weights were measured.

\subsection{Statistical Analysis}

In all greenhouse experiments, treatments were arranged in a randomized block design with four replicates (48 plants per replicate) and the experiments were repeated over time. In the field experiments, all treatments were replicated 4 times and the experiment was repeated in successive years. Data were averaged over the 2-year testing period, after subjecting to Bartlett's test for homogeneity of variance [54].

In both the greenhouse and field experiments, the mean percentages of plant mortalities and biomass reductions were calculated for each treatment, and subjected to Arcsin transformation. The transformed data were statistically compared using analysis of variance (ANOVA) $(\mathrm{P}=0.05)$. Results were back-transformed to the original measurements (percentages) for presentation. Data were analyzed via the PROC MIXED function of SAS v9.3 (SAS Institute, Cary, NC, USA) using a least significant difference of 0.05 . Best-fit regression analysis was utilized in all greenhouse and field experiments.

\section{Results and Discussion}

\subsection{C. truncatum Spore Culture, and Efficacy Pre-Testing}

C. truncatum spores (Figure 2) that were grown and harvested on PDA plates (7 days after inoculation) averaged $1.0 \times 10^{8}$ spores plate $^{-1}$ and spores ranged $15-$ $20 \mu \mathrm{M}$ in length. Preliminary inoculation tests to evaluate pathogen virulence (formulated in SW only) revealed that $100 \%$ mortality occurred on hemp sesbania plants (cotyledonary stage) treated under greenhouse conditions (data not shown). 


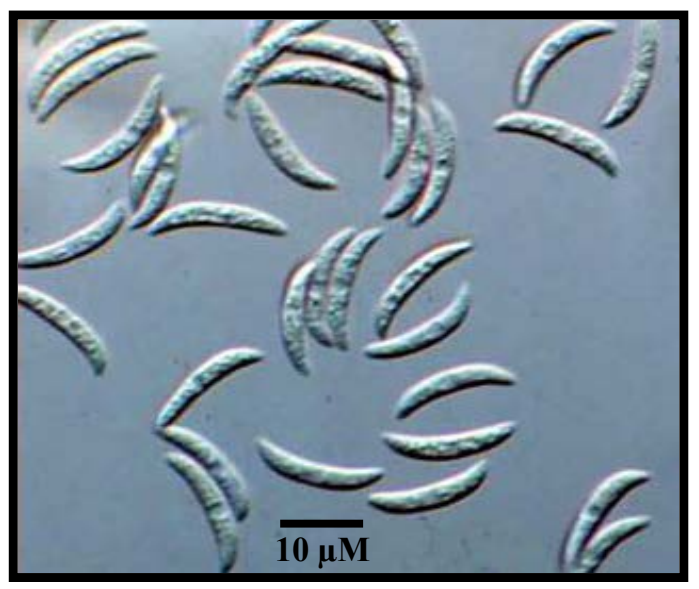

Figure 2. Light micrograph of $C$. truncatum spores.

\subsection{Plant Inoculations: Greenhouse Conditions with a Dew Period}

Inoculation tests revealed that spores were highly virulent to hemp sesbania plants ( $30 \mathrm{~cm}$ tall), i.e., $\sim 100 \%$ mortality of inoculated plants 5 DAT when plants received a hot water $\left(65^{\circ} \mathrm{C}\right)$ pre-treatment, fb spray treatment of CT formulated in SW and/or CO (Figure 3).

SW and SW+CO applications without CT had no effect on mortality or dry weight reduction of hemp sesbania plants when applied following a pre-treatment of water at temperatures of $25^{\circ} \mathrm{C}-35^{\circ} \mathrm{C}$, followed by a 12-h dew period (Figure 4(a) \& Figure 4(b)). CT (formulated with or without CO and/or SW) had some effect on mortality ( $17 \%$ and $30 \%$ for SW and SW+CO, respectively) when applied at $25^{\circ} \mathrm{C}$ (Figure $4(\mathrm{a})$ ). A similar effect was observed on plant dry weight reduction when $\mathrm{CT}$, formulated with $\mathrm{SW}$ or $\mathrm{SW}+\mathrm{CO}$ was applied at $25^{\circ} \mathrm{C}$ (Figure 4(b)). Increased mortality and reductions of dry weight occurred as the water pre-treatment temperature increased, reaching a maximum $(\sim 85 \%)$ on these two parameters at about $65^{\circ} \mathrm{C}$. Although not statistically significant $(\mathrm{P}=$ $0.05)$, the combination of $\mathrm{SW}+\mathrm{CO}+\mathrm{CT}$ tended to be more efficacious than the SW+CT formulation at nearly all water application temperatures (Figure 4(a) \& Figure $4\left(\right.$ b)). However, when a pre-treatment of hot water at $65^{\circ} \mathrm{C}$ was applied, $\mathrm{fb}$ spray treatment of $\mathrm{CT}$ formulated in $\mathrm{CO}+\mathrm{SW}$, significant mortality and dry weight reduction occurred (85\% and 95\%, respectively) (Figure 4(a) \& Figure 4(b)). The adjuvants alone (SW or SW+CO) caused some effects on mortality and dry weight reduction at water pre-treatment temperatures of $40^{\circ} \mathrm{C}-95^{\circ} \mathrm{C}$, but the effects were generally about $35 \%-45 \%$ lower than when combined with the fungus (CT) (Figure 4(a) \& Figure 4(b)).

\subsection{Plant Inoculations: Greenhouse Conditions without a Dew Period}

No significant differences in formulation ( $\mathrm{SW}$ or $\mathrm{SW}+\mathrm{CO}$ ) effects occurred, i.e., only slight differences in mortality and dry weight reductions after pre-treatment 


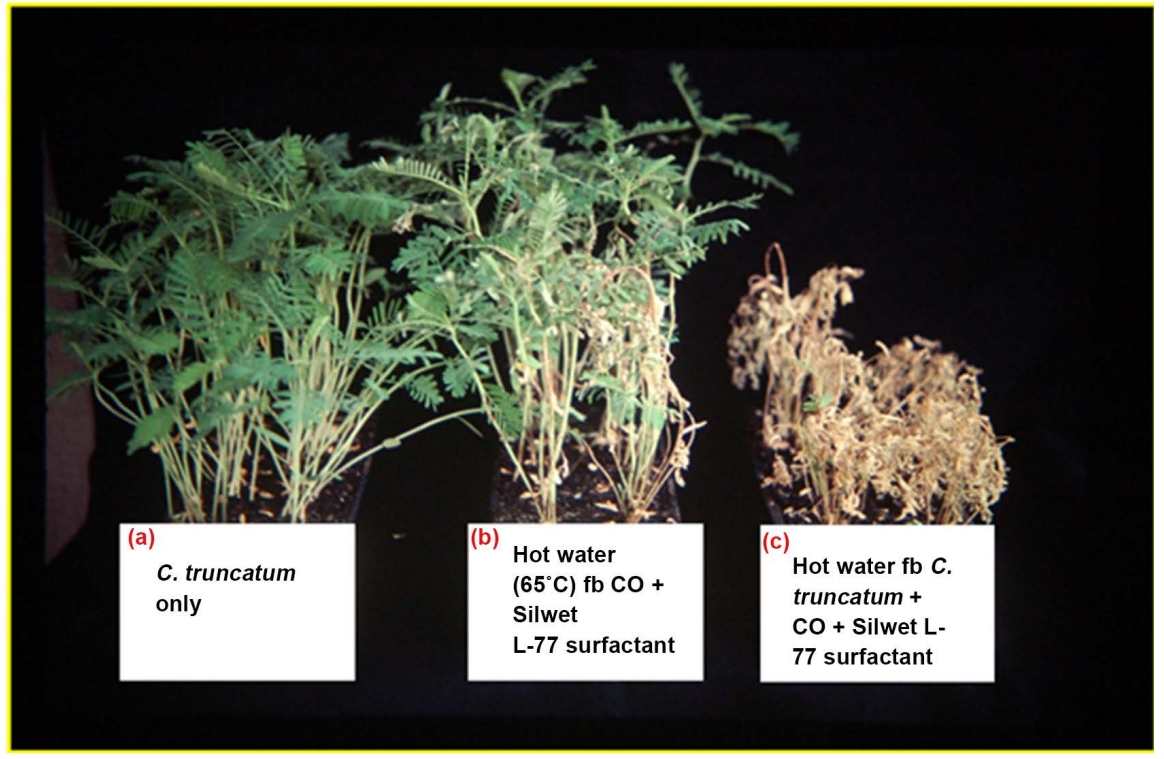

Figure 3. Photograph depicting the effects of hot water pre-treatments on biological control of Sesbania exaltata with Colletotrichum truncatum under greenhouse conditions, 5 DAT. (a) C. truncatum (CT) spores applied at an inoculum concentration of $1.0 \times 10^{7}$ spores. $\mathrm{ml}^{-1}$ suspended in $0.2 \%$ Silwet L-77 surfactant (SW) at a spray rate of about 200 $\mathrm{L} \cdot \mathrm{ha}^{-1}$; (B) hot water $\left(65^{\circ} \mathrm{C}\right)$ applied at a rate of about $200 \mathrm{~L} \cdot \mathrm{ha}^{-1}$ followed by SW $(0.2 \%$, $\mathrm{v}: \mathrm{v})$ in CO:water (1:1, v:v); (c) CT followed by hot water $\left(65^{\circ} \mathrm{C}\right)$ applied at a rate of about $200 \mathrm{~L} \cdot \mathrm{ha}^{-1}$ followed by an emulsion of SW $(0.2 \%, \mathrm{v}: \mathrm{v})$ in CO:water $(1: 1, \mathrm{v}: \mathrm{v})$.

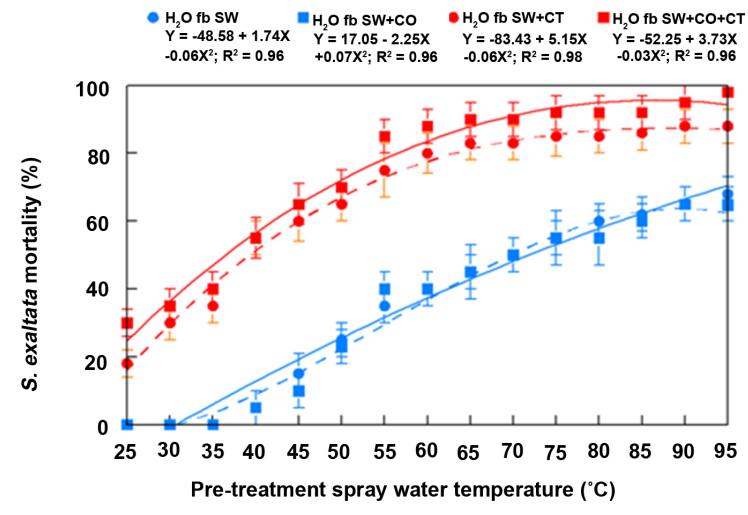

(a)

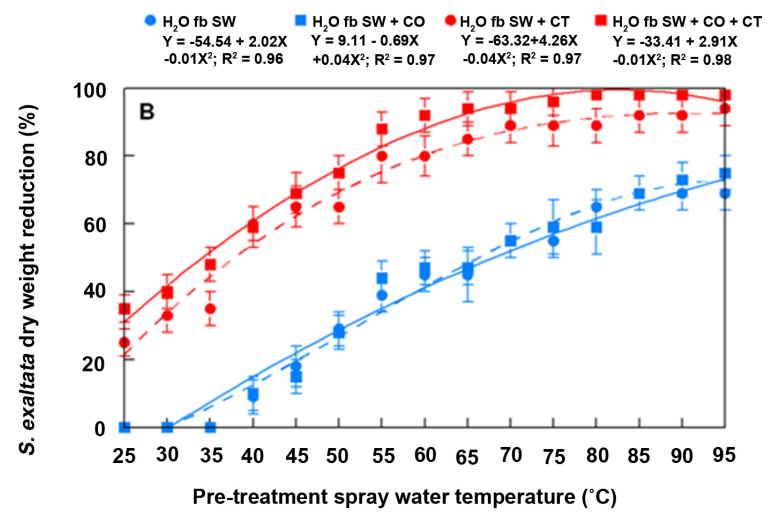

(b)

Figure 4. Effects of various aqueous pre-treatment hot water temperatures applied at a rate of about $200 \mathrm{~L} \cdot \mathrm{ha}^{-1}$ followed by $C$. truncatum spores in various formulations on $S$. exaltata, under greenhouse conditions $\left(28^{\circ} \mathrm{C}-33^{\circ} \mathrm{C}, 60 \%-80 \% \mathrm{RH}, 12 \mathrm{~h}\right.$ day length) following a $12 \mathrm{~h}$ artificial dew treatment $\left(25^{\circ} \mathrm{C}\right)$. (a) = mortality; (b) = dry weight reduction. Regression equations for curves of the data for treatments are presented in the legend above the graphs. Error bars represent \pm 1 SE of means.

of hot water at $55^{\circ} \mathrm{C}-95^{\circ} \mathrm{C}$ in the absence of a dew period (Figure 5(a) \& Figure 5(b)). Thus, dew treatments had little effect on weed mortality or dry weight reductions in these experiments under greenhouse conditions. This contrasts with results found on $C$. coccodes when formulated in another surfactant (Tween 80 ). Dew periods of 4,8 , or $12 \mathrm{~h}$ provided $10 \%, 25 \%$, and $40 \%$ control of eastern black nightshade plants, respectively, when $C$. coccodes spores were 


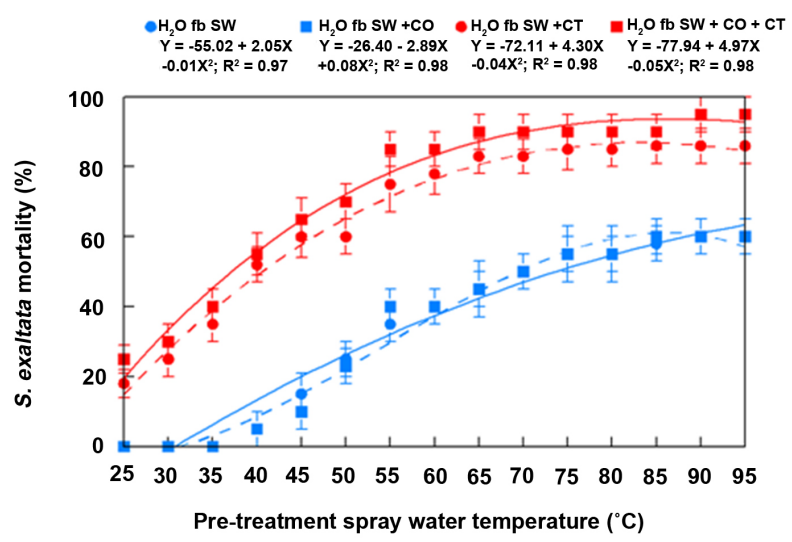

(a)

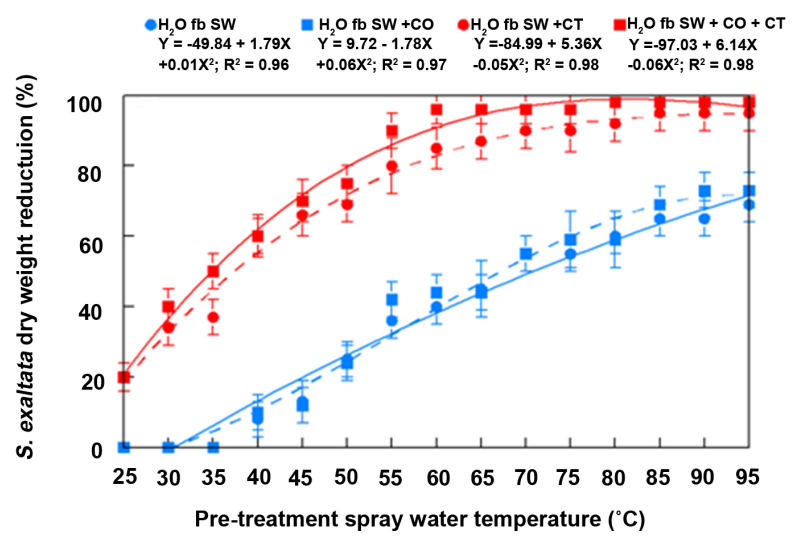

(b)

Figure 5. Effects of various aqueous pre-treatment hot water temperatures applied at a rate of about $200 \mathrm{~L} \cdot \mathrm{ha}^{-1}$ followed by $C$. truncatum spores in various formulations, on (a) mortality of $S$. exaltata or (b) dry weight reduction under greenhouse conditions $\left(28^{\circ} \mathrm{C}-33^{\circ} \mathrm{C}, 60 \%-80 \% \mathrm{RH}, 12 \mathrm{~h}\right.$ day length) without an artificial dew treatment. Regression equations for curves of the data for treatments are presented in the legend above the graphs. Error bars represent \pm 1 SE of means.

applied in water + Tween 20 , but at least $16 \mathrm{~h}$ of dew was required to achieve $\sim 95 \%$ mortality of plants [55].

\subsection{Plant Inoculations: Field Experiments}

Hemp sesbania plants ( $\geq 30 \mathrm{~cm}$ tall) were controlled $75 \%$ - 85\% under field conditions following pre-treatment with hot water $\left(65^{\circ} \mathrm{C}\right) 12$ - $15 \mathrm{DAT}$, with concomitant dry weight reductions (Figure $6 \&$ Figure 7). No re-generative growth occurred in plants that were inoculated with CT following hot water pre-treatments at temperatures $\geq 45^{\circ} \mathrm{C}$ (Data not shown).

Although decent weed control $(75 \%-85 \%)$ was achieved in these experiments, application of hot water coupled with CT at an earlier stage of weed development when plants are more sensitive, would likely result in higher efficacy. Formulations of this bioherbicide have previously been shown to provide excellent control ( $\geq 95 \%)$ of seedling (cotyledonary to first true-leaf stage) hemp sesbania seedlings [56]. In those experiments, SW was used in combinations with an invert emulsion. Although excellent weed control was achieved with this combination, a formulation of SW + CT failed to provide acceptable hemp sesbania control.

\section{Conclusions}

Hemp sesbania plants $\left(>30 \mathrm{~cm}\right.$ tall) sprayed with hot water $\left(65^{\circ} \mathrm{C}-95^{\circ} \mathrm{C}\right)$, followed by spray applications of fungal spores of Colletotrichum truncatum $(1.0 \times$ $10^{7}$ spores $\cdot \mathrm{ml}^{-1}$ ) were controlled $90 \%$ - 95\% under greenhouse conditions and $75 \%-85 \%$ under field conditions, 15 DAT. Plants treated with the fungus without hot water $\left(25^{\circ} \mathrm{C}\right)$ pre-treatment were visually unaffected and no plant growth reductions or plant biomass reductions occurred 15 DAT. Plants treated with hot water without fungus were wilted at temperatures $\geq 45^{\circ} \mathrm{C}$. It is important to 


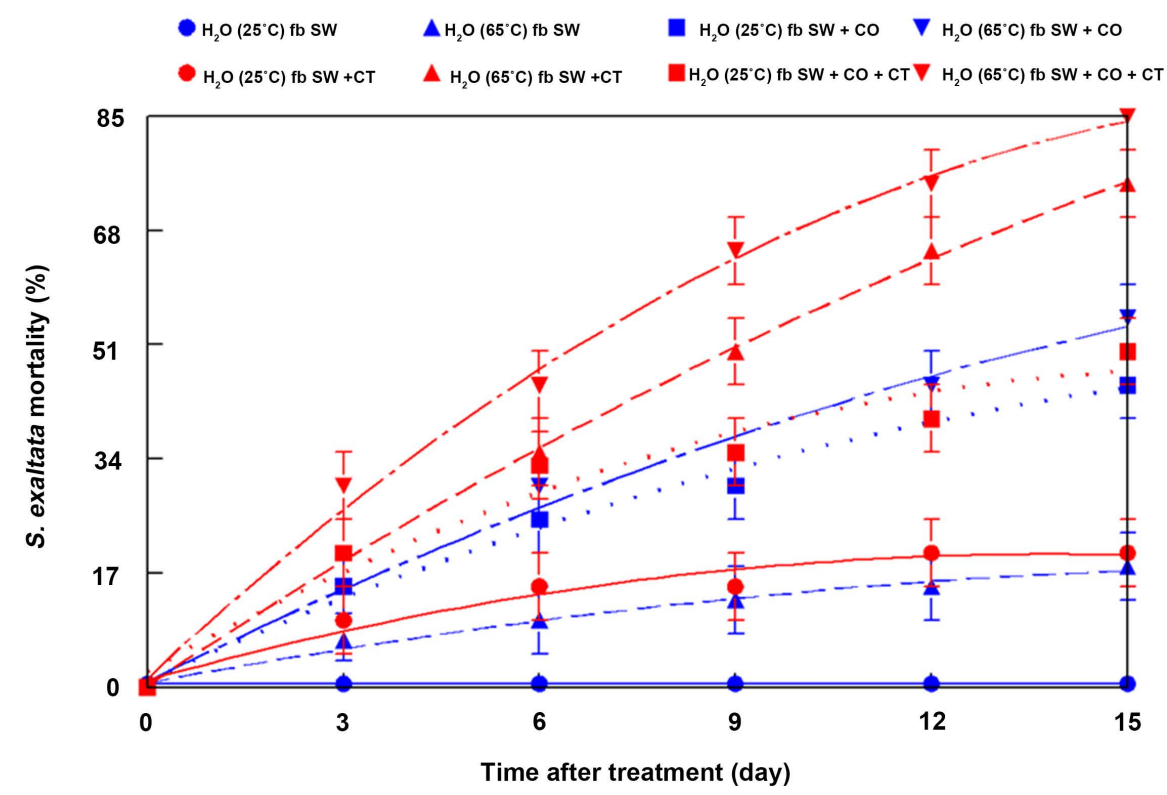

Figure 6. Effects of hot water treatment followed by inoculation with $C$. truncatum on hemp sesbania mortality under field conditions. Colored symbols indicate treatments; regression equations of data points are presented in parenthesis. $\bullet=\mathrm{H}_{2} \mathrm{O}$ at $25^{\circ} \mathrm{C}$ followed by SW $\left(\mathrm{Y}=1 ; \mathrm{R}^{2}=1.00\right) ; \bullet=\mathrm{H}_{2} \mathrm{O}$ at $25^{\circ} \mathrm{C}$ followed by $\mathrm{SW}+\mathrm{CT}(\mathrm{Y}=1.07+2.73 \mathrm{X}-1.00$ $\left.\mathrm{X}^{2} ; \mathrm{R}^{2}=0.96\right) ; \boldsymbol{\Delta}=\mathrm{H}_{2} \mathrm{O}$ at $65^{\circ} \mathrm{C}$ followed by SW $\left(\mathrm{Y}=0.71+1.83 \mathrm{X}-0.05 \mathrm{X}^{2} ; \mathrm{R}^{2}=0.98\right) ;$ $\boldsymbol{\Delta}=\mathrm{H}_{2} \mathrm{O}$ at $65^{\circ} \mathrm{C}$ followed by SW $+\mathrm{CT}\left(\mathrm{Y}=0.36+6.49 \mathrm{X}-0.98 \mathrm{X}^{2} ; \mathrm{R}^{2}=0.98\right) ; \cdot=\mathrm{H}_{2} \mathrm{O}$ at $25^{\circ} \mathrm{C}$ followed by SW $+\mathrm{CO}\left(\mathrm{Y}=1.07+4.39 \mathrm{X}-1.00 \mathrm{X}^{2} ; \mathrm{R}^{2}=0.98\right) ; \cdot=\mathrm{H}_{2} \mathrm{O}$ at $25^{\circ} \mathrm{C}$ followed by SW + CO + CT $\left(\mathrm{Y}=2.50+5.41 \mathrm{X}-0.16 \mathrm{X}^{2} ; \mathrm{R}^{2}=0.96\right) ; \boldsymbol{\nabla}=\mathrm{H}_{2} \mathrm{O}$ at $65^{\circ} \mathrm{C}$ followed by SW $+\mathrm{CO}\left(\mathrm{Y}=0.89+4.86 \mathrm{X}-0.90 \mathrm{X}^{2} ; \mathrm{R}^{2}=0.98\right) ; \boldsymbol{\nabla}=\mathrm{H}_{2} \mathrm{O}$ at $65^{\circ} \mathrm{C}$ followed by $\mathrm{SW}+\mathrm{CO}+\mathrm{CT}\left(\mathrm{Y}=1.43+9.10 \mathrm{X}-0.24 \mathrm{X}^{2} ; \mathrm{R}^{2}=0.98\right)$. Error bars $= \pm 1 \mathrm{SD}$.

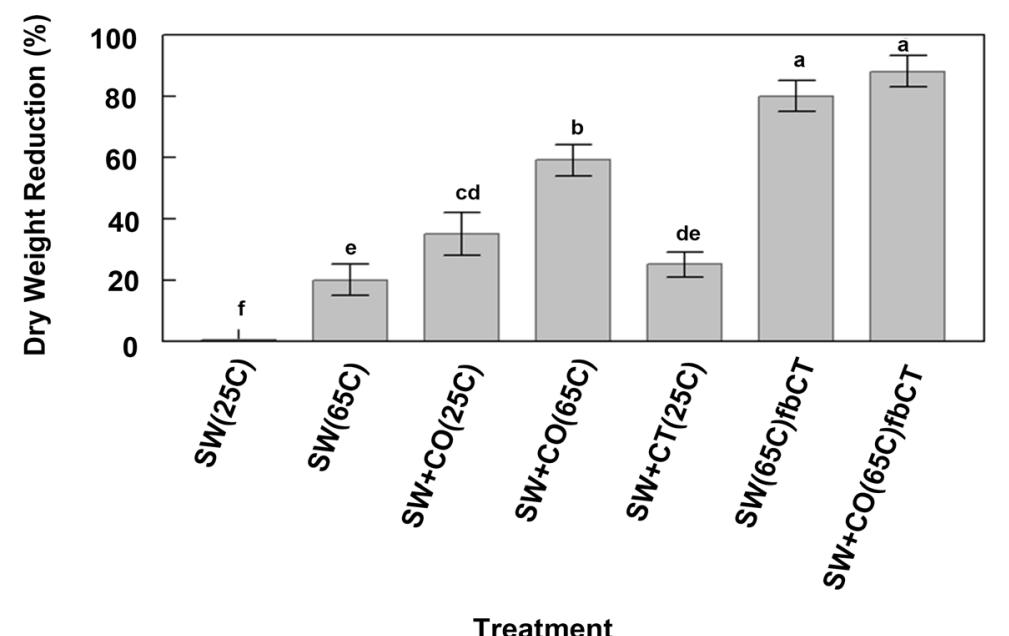

Figure 7. Effects of hot water treatment followed by inoculation with $C$. truncatum on hemp sesbania dry weight reduction under field conditions. Error bars $= \pm 1$ SD. Histogram bars with the same letter are not different at $\mathrm{p}=0.05$ according to Fisher's LSD $(\mathrm{P}=0.05)$.

note that no re-generative growth occurred in plants that were inoculated with $\mathrm{CT}$ following hot water pre-treatments at temperatures $\geq 45^{\circ} \mathrm{C}$. CT formulated 
with $\mathrm{SW}+\mathrm{CO}$ has previously been shown to greatly reduce the dew requirements required for infection and control of hemp sesbania [42]. Since dew is highly unpredictable under field conditions, the use of a hot water pre-treatment on weeds may preclude the necessity for free-moisture or dew event. This research represents a new approach for weed control using biological agents (bioherbicides). This is the first report of the use of hot water to predispose a weed to the effects of a bioherbicidal plant pathogen. Because transporting large volumes of water are inconvenient and expensive, and water that misses the target weed foliage can represent significant energy losses, this technology may be better suited for use in aquatic biological weed control situations.

Future research will be needed to transform this concept into an economical and efficient technology for weed control. Engineering will be required to develop application equipment with high efficiency for transporting/applying hot water in field cropping situations. This research investigated the effects of hot water and a bioherbicidal pathogen in a non-cropping situation. However, the possible effects of hot water injury and/or pathogen interactions on various crops will need to be investigated to ensure safety. Overall, the results suggest that use of hot water may be an important tool for improving the infectivity and bioherbicidal potential of $C$. truncatum on hemp sesbania. This innovative approach may also be useful to increase the efficacy of some other plant pathogens against their weed targets.

\section{Acknowledgements}

The authors thank Robin H. Jordan for expert laboratory and data graphics assistance during this project.

\section{Conflicts of Interest}

The authors declare no conflicts of interest regarding the publication of this paper.

\section{References}

[1] Ellwanger Jr., T.C., Bingham, S.W. and Chappell, W.E. (1973) Physiological Effects of Ultra-High Temperatures on Corn. Weed Science, 21, 296-299.

[2] Ellwanger Jr., T.C., Bingham, S.W., Chappell, W.E. and Tolin, S.A. (1973) Cytological Effects of Ultra-High Temperatures on Corn. Weed Science, 21, 299-303.

[3] Sutcliffe, J. (1977) Plants and Temperature. Edward Arnold, London.

[4] Levitt, J. (1980) Responses of Plants to Environmental Stresses. Vol. I: Chilling, Freezing, and High Temperature Stresses. 2nd Edition, Academic Press, New York.

[5] Daniell, J.W., Chappell, W.E. and Couch, H.B. (1969) Effect of Sublethal and Lethal Temperatures on Plant Cells. Plant Physiology, 44, 1684-1689.

https://doi.org/10.1104/pp.44.12.1684

[6] Porterfield, J.G., Batchelder, D.G., Bashford, L. and McLaughlin, G. (1971) Two Stage Thermal Defoliation. National LP-Gas Association and Natural Gas Processors Association, Dallas, TX, 32-34. 
[7] Hoffmann, M. (1989) Abflammtechnik. KTBL-Schrift 331. Landwirtschaftsverlag, Münster-Hiltrup.

[8] Thomas, C.H. (1964) Technical Aspects of Flame Weeding in Louisiana. Natural Gas Processors Association, Memphis, TN, 28-33.

[9] D’Antonio, C.M. (2000) Fire, Plant Invasions, and Global Changes. In: Mooney, H.A. and Hobbs, R.J., Eds., Invasive Species in a Changing World, Island Press, Washington DC, 65-93.

[10] Ascard, J., Hatcher, P.E., Melander, B. and Upadhyaya, M.K. (2007) Thermal Weed Control. In: Upadhyaya, M.K. and Blackshaw, R.E., Eds., Non-Chemical Weed Management, CAB International, Wallingford, 155-175.

[11] Kepner, R.A., Bainer, R. and Barger, E.L. (1978) Principles of Farm Machinery. 3rd Edition, AVI, Westport, CT.

[12] Laguë, C., Gill, J. and Péloquin, G. (2001) Thermal Control in Plant Protection. In: Vincent, C., Panneton, B. and Fleurat-Lessard, F., Eds., Physical Control Methods in Plant Protection, Springer-Verlag, Berlin, 35-46. https://doi.org/10.1007/978-3-662-04584-8_2

[13] Dierauer, H.U. and Stöppler-Zimmer, H. (1994) Unkrautregulierung ohne Chemie. Ulmer, Stuttgart.

[14] Rasmussen, J. and Ascard, J. (1995) Weed Control in Organic Farming Systems. In: Glen, D.M., Greaves, M.P. and Anderson, H.M., Eds., Ecology and Integrated Farming Systems: Proceedings of the 13 th Long Ashton International Symposium, Wiley, Chichester, 49-67.

[15] Melander, B. and Rasmussen, G. (2001) Effects of Cultural Methods and Physical Weed Control on Intrarow Weed Numbers, Manual Weeding and Marketable Yield in Direct-Sown Leek and Bulb Onion. Weed Research, 41, 491-508. https://doi.org/10.1046/j.1365-3180.2001.00252.x

[16] Ascard, J. (1998) Comparison of Flaming and Infrared Radiation Techniques for Thermal Weed Control. Weed Research, 38, 69-76. https://doi.org/10.1046/j.1365-3180.1998.00073.x

[17] Quarles, W. (2001) Improved Hot Water Weed Control System. IPM Practitioner, 23, 1-4.

[18] Scheible, A. (1895) Apparatus for Exterminating Vegetation. US Patent No. 546, 682.

[19] Kolberg, R.L. and Wiles, L.J. (2002) Effect of Steam Application on Cropland Weeds. Weed Technology, 16, 43-49. https://doi.org/10.1614/0890-037X(2002)016[0043:EOSAOC]2.0.CO;2

[20] Upadhyaya, M.K., Polster, D.F. and Klassen, M.J. (1993) Weed Control by Superheated Steam. Weed Science Society of America Abstracts, 33, 115.

[21] Kurfess, W. and Kleisinger, S. (2000) Effect of Hot Water on Weeds. Zeitschrift für Pflanzenkrankheiten und Pflanzenschutz, 17, 473-477.

[22] Hansson, D. and Ascard, J. (2002) Influence of Developmental Stage and Time of Assessment on Hot Water Weed Control. Weed Research, 42, 307-316. https://doi.org/10.1046/j.1365-3180.2002.00290.x

[23] Heap, I. (2017) The International Survey of Herbicide Resistant Weeds. http://www.weedscience.org

[24] Charudattan, R. and Walker, H.L. (1982) Biological Control of Weeds with Plant Pathogens. Wiley, New York. 
[25] Hoagland, R.E. (1990) Microbes and Microbial Products as Herbicides, American Chemical Society Symposium Series No. 439. ACS Books, Washington DC.

[26] TeBeest, D.O. (1991) Microbial Control of Weeds. Chapman and Hall, New York. https://doi.org/10.1007/978-1-4615-9680-6

[27] TeBeest, D.O. and Templeton, G.E. (1985) Mycoherbicides: Progress in the Biological Control of Weeds. Plant Disease, 69, 6-10.

[28] Charudattan, R. (2001) Biological Control of Weeds by Means of Plant Pathogens: Significance for Integrated Weed Management in Modern Agro-Ecology. BioControl, 46, 229-260. https://doi.org/10.1023/A:1011477531101

[29] Charudattan, R. (2005) Ecological, Practical, and Political Inputs into Selection of Weed Targets: What Makes a Good Biological Control Target? Biological Control, 35, 183-196. https://doi.org/10.1016/j.biocontrol.2005.07.009

[30] Boyetchko, S.M. and Peng, G. (2004) Challenges and Strategies for Development of Mycoherbicides. In: Arora, D.K., Ed., Fungal Biotechnology in Agricultural, Food, and Environmental Applications, Marcel Dekker, New York, 11-121.

[31] Ghorbani, R., Leifert, C. and Seel, W. (2005) Biological Control of Weeds with Antagonistic Plant Pathogens. Advances in Agronomy, 86, 191-225. https://doi.org/10.1016/S0065-2113(05)86004-3

[32] Hallett, S.G. (2005) Symposium: Where Are the Bioherbicides? Weed Science, 53, 404-415. https://doi.org/10.1614/WS-04-157R2

[33] Weaver, M.A., Lyn, M.E., Boyette, C.D. and Hoagland, R.E. (2007) Bioherbicides for Weed Control. In: Upadhyaya, M.K. and Blackshaw, R.E., Eds., Non-Chemical Weed Management, CAB International, Wallingford, 93-110. https://doi.org/10.1079/9781845932909.0093

[34] Bailey, K.L. (2014) The Bioherbicide Approach to Weed Control Using Plant Pathogens. In: Abrol, D.P., Ed., Integrated Pest Management. Current Concepts and Ecological Perspectives, Elsevier, San Diego, 245-266. https://doi.org/10.1016/B978-0-12-398529-3.00014-2

[35] Duke, S.O., Scheffler, B.E., Boyette, C.D. and Dayan, F.E. (2015) Biotechnology in Weed Control. In: Kirk-Othmer Encyclopedia of Chemical Technology, John Wiley \& Sons, New York, 1-25. https://doi.org/10.1002/0471238961.herbduke.a01.pub2

[36] Cordeau, S., Triolet, M., Waymon, S., Steinberg, C. and Guillemin, J.P. (2016) Bioherbicides: Dead in Water? Crop Protection, 87, 44-49. https://doi.org/10.1016/j.cropro.2016.04.016

[37] Hoagland, R.E. and Boyette, C.D. (2016) Controlling Herbicide-Susceptible, -Tolerant and -Resistant Weeds with Microbial Bioherbicides. Outlooks on Pest Management, 27, 256-266. https://doi.org/10.1564/v27_dec_04

[38] Mintz, A.S., Heiny, D.K. and Weidemann, G.J. (1992) Factors Influencing the Biocontrol of Tumble Pigweed (Amaranthus albus) with Aposphaeria amaranthi. Plant Disease, 76, 267-269. https://doi.org/10.1094/PD-76-0267

[39] Quimby, P.C., Fulgham, F.E., Boyette, C.D. and Connick, W.J. (1989) An Invert Emulsion Replaces Dew in Biocontrol of Sicklepod-A Preliminary Study. In: Hovde, D. and Beestman, G.B., Eds., Pesticide Formulations and Application Systems, American Society for Testing Materials, West Conshohocken, 267-270.

[40] Auld, B.A. (1993) Vegetable Oil Suspension Emulsions Reduce Dew Dependence of a Mycoherbicide. Crop Protection, 12, 477-479. https://doi.org/10.1016/0261-2194(93)90011-7

[41] Boyette, C.D., Quimby, P.C., Bryson, C.T., Egley, G.H. and Fulgham, F.E. (1993) 
Biological Control of Hemp Sesbania (Sesbania exaltata) under Field Conditions with Colletotrichum truncatum Formulated in an Invert Emulsion. Weed Science, 41, 497-500.

[42] Boyette, C.D. (1994) Unrefined Corn Oil Improves the Mycoherbicidal Activity of Colletotrichum truncatum for Hemp Sesbania (Sesbania exaltata) Control. Weed Technology, 8, 526-528. https://doi.org/10.1017/S0890037X00039622

[43] Egley, G.E. and Boyette, C.D. (1995) Water-Unrefined Corn Oil Emulsions Enhances Conidia Germination and Mycoherbicidal Activity of Colletotrichum truncatum. Weed Science, 43, 312-317.

[44] Sandrin, T.R., TeBeest, D.O. and Weidemann, G.J. (2003) Soybean and Sunflower Oils Increase the Infectivity of Colletotrichum gloeosporioides $\mathrm{f}$. sp. aeschynomene to Northern Jointvetch. Biological Control, 26, 244-252. https://doi.org/10.1016/S1049-9644(02)00156-1

[45] Abbas, H.K. and Boyette, C.D. (2000) Solid Substrate Formulation of the Mycoherbicide Colletotrichum truncatum for Hemp Sesbania (Sesbania exaltata) Control. Biocontrol Science and Technology, 10, 291-300. https://doi.org/10.1080/09583150050044565

[46] Boyette, C.D. (1991) Control of Hemp Sesbania with a Fungal Pathogen, Colletotrichum truncatum. U.S. Patent No. 5, 034, 328.

[47] Boyette, C.D., Hoagland, R.E. and Weaver, M.A. (2008) Interaction of a Bioherbicide and Glyphosate for Controlling Hemp Sesbania in Glyphosate-Resistant Soybean. Weed Biology and Management, 8, 18-24. https://doi.org/10.1111/j.1445-6664.2007.00269.x

[48] Boyette, C.D. and Hoagland, R.E. (2013) Adjuvant and Refined Corn Oil Formulation Effects on Conidial Germination, Appressorial Formation and Virulence of the Bioherbicide, Colletotrichum truncatum. Plant Pathology Journal, 12, 50-60. https://doi.org/10.3923/ppj.2013.50.60

[49] Abbas, H.K. and Egley, G.H. (1996) Influence of Unrefined Corn Oil and Surface-Active Agents on the Germination and Infectivity of Alternaria helianthi. Biocontrol Science and Technology, 6, 531-538. https://doi.org/10.1080/09583159631163

[50] Dowler, C.C. (1992) Weed Survey-Southern States. Proceedings of the Southern Weed Science Society, 45, 392-407.

[51] Jordan, D.L., York, A.C., Griffin, J.L., Clay, P.A., Vidrine, P.R. and Reynolds, D.B. (1997) Influence of Application Variables of Efficacy on Glyphosate. Weed Technology, 11, 354-362. https://doi.org/10.1017/S0890037X00043062

[52] Shaw, D.R. and Arnold, J.C. (2002) Weed Control from Herbicide Combinations with Glyphosate. Weed Technology, 16, 1-6. https://doi.org/10.1614/0890-037X(2002)016[0001:WCFHCW]2.0.CO;2

[53] Bakerspigel, A. (1953) Soils as a Storage Medium for Fungi. Mycologia, 45, 596-604.

[54] Gomez, K.A. and Gomez, A.A. (1984) Statistical Procedures for Agricultural Research. 2nd Edition, Wiley, New York.

[55] Boyette, C.D., Hoagland, R.E. and Stetina, K.C. (2016) Efficacy Improvement of a Bioherbicidal Fungus Using a Formulation-Based Approach. American Journal of Plant Sciences, 7, 2349-2358. https://doi.org/10.4236/ajps.2016.716206

[56] Boyette, C.D., Hoagland, R.E. and Weaver, M.A. (2007) Biocontrol Efficacy of Colletotrichum truncatum for Hemp Sesbania (Sesbania exaltata) Is Enhanced with Unrefined Corn Oil and Surfactant. Weed Biology and Management, 7, 70-76. https://doi.org/10.1111/j.1445-6664.2006.00230.x 